\title{
A Study of Job Satisfaction amongst Delhi University Faculty Based On Seniority of Post
}

\author{
Narander Kumar Nigam ${ }^{1}$, Saumya Jain ${ }^{2}$ \\ ${ }^{I}$ (Research Scholar, Department of Financial Studies,University of Delhi) \\ ${ }^{2}$ (Assistant professor, Shri Ram College of Commerce,University of Delhi)
}

\begin{abstract}
Teachers at the undergraduate level play an important role in shaping the lives of students who stand at the crossroads of their career. The commitment and dedication of teachers, among other factors depend upon their level of satisfaction with their job. No empirical research has been done regarding the level of satisfaction in teachers engaged in one of the most prestigious universities of the country, University of Delhi. The present study was designed to assess the job satisfaction level of Delhi university faculty and to find out whether level of job satisfaction was influenced by position in organisational hierarchy. Little is known about faculty job satisfaction in higher education as well as in the developing countries like India. The present study was designed to assess the job satisfaction level of Delhi university faculty and to find out whether level of job satisfaction was influenced by the seniority in the hierarchy. The study makes a comparison between satisfaction of Assistant professors and Associate professors across three disciplines namely Arts, Science \& Arts. The study was a descriptive study and made use of standardized job satisfaction scale as a research tool. 163 faculty members working in Delhi University in 18 different colleges were selected. The findings of study showed that most academic members of Delhi universities were satisfied with their job. However, there were different in satisfaction at the same level across academic streams.
\end{abstract}

Keywords: Assistant, Associate, Delhi university, ,Faculty, , Satisfaction ,Science.

\section{Introduction}

“ I was worth over $\$ 1,000,000$ when I was 23 , and over $\$ 10,000,000$ when I was 24 , and it wasn't that important because I never did it for money".

\section{Steve Jobs (Co-founder Apple Inc)}

The above mentioned line highlights how different people respond to success and achievements in life. As a person gets promoted in his/her job, his pay scale increases, his work profile changes and his privileges and reputation increases. All these factors influence performance and attitude towards work. An attempt was made to analyse whether seniority of position at work affects job satisfaction through survey amongst faculty in University of Delhi working at two levels: Associate Professor \& Assistant Professor. The profession of teaching was chosen because teachers have a great deal of influence on the students and their commitment and dedication affects the quality of teaching. The study is aimed at assessing whether people at higher levels are more/less satisfied than those working at lower levels and what are the factors contributing to satisafaction/dissatisfaction. In the next section, a number of articles have been reviewed that aim at identifying the factors contributing to satisfaction in education industry.

\section{Literature Review}

Quality in teaching and learning can only enhanced if the faculty members are satisfied and content (Chen, 2006). In 1994, Luthans defined Job satisfaction as "an attitude developed by an individual towards the job and job conditions". In 1997Spector refined the definition of job satisfaction to constitute an attitudinal variable that measures how a person feels about his or her job, including different facets of the job. Telman\&Unsal 2004 classified the factors affecting job satisfaction into internal, external and personal. Internal factors include characteristics inherent to the nature of work. External factors are the conditions such as job responsibilities, promotion criteria, equation with superiors and co -workers, creativity, job security, organizational structure and culture. Personal factors include factors such as gender, age, length of service, educational level ,personality traits and incentive, knowledge and skills. There are several recent studies that have addressed the question of job satisfaction among academic members of higher education in Asia - Pacific area. Regarding the relationship between faculty job satisfaction and demographic variable of academics in a public higher education in Singapore, Paul and Phua (2011) indicated that respondents related satisfaction with interpersonal relationships with students and co-workers, the autonomy and flexibility that the job offered. Conversely, they expressed dissatisfaction over the amount of administrative/non academic work they had to shoulder, heavy workload, salary, presence of 'red tape' and other corporate practices and dealing with disruptive students. Age and job position affected the job satisfaction levels of the respondents. However, 
variables such as gender, academic qualification, length of employment and marital status showed no significant difference. The study of Noordin and Jusoff (2009) comprised two hundred and thirty-seven of academics from a public university in Malaysia that overall the academic staff of the university has a moderate level of job satisfaction. In addition, current status, marital status, age and salary appear to have significant impact on the respondents' level of job satisfaction. In their research with faculty from three private universities in Malaysia, Santhapparaj and Alam (2005) found that pay, promotion, working condition and support of research have positive and significant effect on job satisfaction. Regarding the relationship between incentives, rewards and recognition on employee motivation and job satisfaction of two hundred and nineteen of academic member of Hue University in Vietnam, Nguyen et al., (2013) found that significantly positive relationship between reward and recognition, satisfaction with supervision and the job characteristics, with job satisfaction as well as a very positive and significant relationship was also observed between job satisfaction and personal motivation.Sabharwal\& Corley (2009) concluded that across all disciplines, female faculty members expressed lower levels of satisfaction when compared with male faculty members and that women might place a greater emphasis on intrinsic (contribution to the society, opportunities for advancement, intellectual challenges) than extrinsic factors (salary and benefits).

\section{Need Of The Study}

University of Delhi is a premier educational body that attracts students from all over the world. Given the high regard which parents, students, academicians and foreign universities attribute to this institution it becomes necessary to examine how motivated the faculty members are with respect to their duties and the level of satisfaction and security they have at work. Delhi University has thousands of teachers working at various levels and this study attempts to make intra post across streams and inter post comparison of job satisfaction and identify whether hierarchy in the organisational structure has any affect on job satisfaction. This study has been done post the introduction of historic change in undergraduate education-the introduction of Four Year Undergraduate Program (FYUP) so as to present the most recent trend in job satisfaction. It is hoped that this study can become the reference point for addressing the concerns of the teachers.

\section{Objectives Of The Study}

The following were the objectives of the study:

1. To undertake study of job satisfaction of the faculty of Delhi university.

2. To study the impact of Academic streams on job satisfaction.

3. To find the causes of job satisfaction and job dissatisfaction of the faculty in each Academic stream.

\section{Research Hypothesis}

1. Job satisfaction of faculty incommerce/economics is equaltofaculty inarts.

2. Job satisfaction of faculty incommerce/economics is equaltofaculty inscience.

3. Job satisfaction of faculty inarts is equaltofaculty inscience.

\subsection{Sampling Design}

\section{Research Methodology}

At present, there are 16 faculties, 86 academic departments, 77 colleges and 5 other recognised institutes spread all over the city. The current research focuses job satisfaction on two levels across different academic streams. So in order to find job satisfaction in Delhi University, 18 colleges were chosen out of 77 . In this study we took three stream namely as Arts, science and commerce/economics to see the impact of designation (assistant Professor/ associate professor) on job satisfaction. Including both Assistant Professors and Associate professors, in our data 47 are faculty in arts, 73 are faculty in commerce/economics faculty and 43 are faculty in science.

TABLE 1 : Academic Stream of respondents

\begin{tabular}{|cc|c|c|c|c|}
\hline & & Frequency & Percent & Valid Percent & Cumulative Percent \\
\hline \multirow{4}{*}{ Valid } & Arts & 47 & 28.8 & 28.8 & 28.8 \\
& commerce/economics & 73 & 44.8 & 44.8 & 73.6 \\
& Science & 43 & 26.4 & 26.4 & 100.0 \\
& Total & 163 & 100.0 & 100.0 & \\
\hline
\end{tabular}

On the basis of designation, there are 121 are Assistant Professors and 42 are Associate Professors 
TABLE 2 : Designation of respondents

\begin{tabular}{|ll|l|l|l|l|}
\hline \multicolumn{1}{|c|}{} & Frequency & Percent & Valid Percent & Cumulative Percent \\
\hline \multirow{2}{*}{ Valid } & Assistant professor & 121 & 74.2 & 74.2 & 74.2 \\
& Associate professor & 42 & 25.8 & 25.8 & 100.0 \\
& Total & 163 & 100.0 & 100.0 & \\
\hline
\end{tabular}

On the basis of gender, there are 84 females and 79 male faculty members.

TABLE 3 : Gender of respondents

\begin{tabular}{|ll|l|l|l|l|}
\hline & Frequency & Percent & Valid Percent & Cumulative Percent \\
\hline \multirow{3}{*}{ Valid } & Female & 84 & 51.5 & 51.5 & 51.5 \\
& Male & 79 & 48.5 & 48.5 & 100.0 \\
& Total & 163 & 100.0 & 100.0 & \\
\hline
\end{tabular}

\subsection{Pretesting}

It was pretested (self-administered tests) on a sample of 12 respondents who were chosen as a result of judgment sampling and feedback was considered in finalizing the questionnaire.

\subsection{Results of Pretesting}

Cronbach Alphawas computed to know the reliability of our data. Cronbach Alpha for internal consistency was .701 which shows that there is reliability and internal consistency.Not all correlations among the questions were less than 0.5 . Finally a set of 24 questions were zeroed on to proceed onto next stage i.e. data collection.

\subsection{Dependent and independent variables}

Job satisfaction has been identified as the dependent variable in this study. It consists of seventeen dimensions of five aspects. The first aspect isnature of Job such asqualification, manageable workload, and atmosphere contributing to professional growth, academic challenges, and sufficient freedom. The second aspect isBenefits from Job such as satisfactory salary, job security, growth opportunities, and learning opportunities. The third aspect is Social Relations such as cooperation from colleagues, responsive seniors, and student's interaction. The fourth aspect isManagerial Aspects of Job such aswork recognition, employee friendly management policies, and extent of involvement in management decisions. The fifth aspect is such as Facilities: infrastructure facilities and welfare facilities.

\subsection{Data Analysis Method}

Questionnaire survey was used to gather data in this study. There were 17 questions in questionnaire and each question has 5 options $(1=$ Strongly Disagree, $2=$ Disagree, $3=$ Neutral, $4=$ Agree, $5=$ Strongly Agree.)The respondents were weighted on a 4-point Likert's scale to measure job satisfaction of faculty in Delhi university $(1=$ Very Dissatisfied, $2=$ Dissatisfied, $3=$ Satisfied, $4=$ Very Satisfied $)$. The questions were combined into one summated scale on which the tests were performed.

$1=$ Less than to equal 33,

$2=$ Between $34-50$,

$3=$ Between 51-67,

$4=$ More than equal to 68 .

All data were analyzed using the Statistical Package for the Social Sciences (SPSS) 20.0 software. As the number of respondents are more than 30 , data is normally distributed and all parametric tests can be applied (Central Limit Theorem).

\subsection{Statistical Tools Used}

1. Co-efficient of Reliability

2. Student's ' $t$ '- test

3. Test of Homogeneity of Variances

4. ANOVA

5. Arithmetic mean and median 
7.1Reliability

\section{Results And Discussion}

In this research, internal consistency analysis was conducted to assess the reliability of this constructed measurement for job satisfaction of academic members. All five aspects were identified to measure the variable of job satisfaction which is the dependent variable of this study.

TABLE 4 : Reliability Statistics

\begin{tabular}{|r|r|r|}
\hline Cronbach's Alpha & Cronbach's Alpha Based on Standardized Items & N of Items \\
\hline .761 & .810 & 17 \\
\hline
\end{tabular}

The internal consistency analysis yielded Cronbach's alpha coefficients 0.761 , which is significantly higher than the 0.7. Hence, based on the validation of construct reliability it was concluded that research construct of job satisfaction is reliable in this study.

\subsection{Satisfaction level of Assistant Professors \& Associate Professors}

As sample size is two so "T" test is applied as samples are independent. According to our scale , Mean score of job satisfaction in Assistant professor is 62.33 and Standard Deviation is 7.402. This means Assistant professors are generally satisfied. For Associate Professors, mean score of job satisfaction is 60.97 and Standard Deviation is 10.74. This implies that Associate Professors are also satisfied.

TABLE 5 : Group Statistics

\begin{tabular}{|l|l|l|l|l|l|}
\hline & Designation of respondent & N & Mean & Std. Deviation & Std. Error Mean \\
\hline \multirow{2}{*}{ jst } & Assistant professor & 121 & 62.3306 & 7.40201 & .67291 \\
& Associate professor & 42 & 60.9762 & 10.74423 & 1.65787 \\
\hline
\end{tabular}

At significance level of 5\%, job satisfaction of Assistant professors and Associate professors are not significantly different as p value shows .452 (assumed variance not equal) which is more than .05. Both are equally satisfied.

TABLE 6 : Independent Samples Test

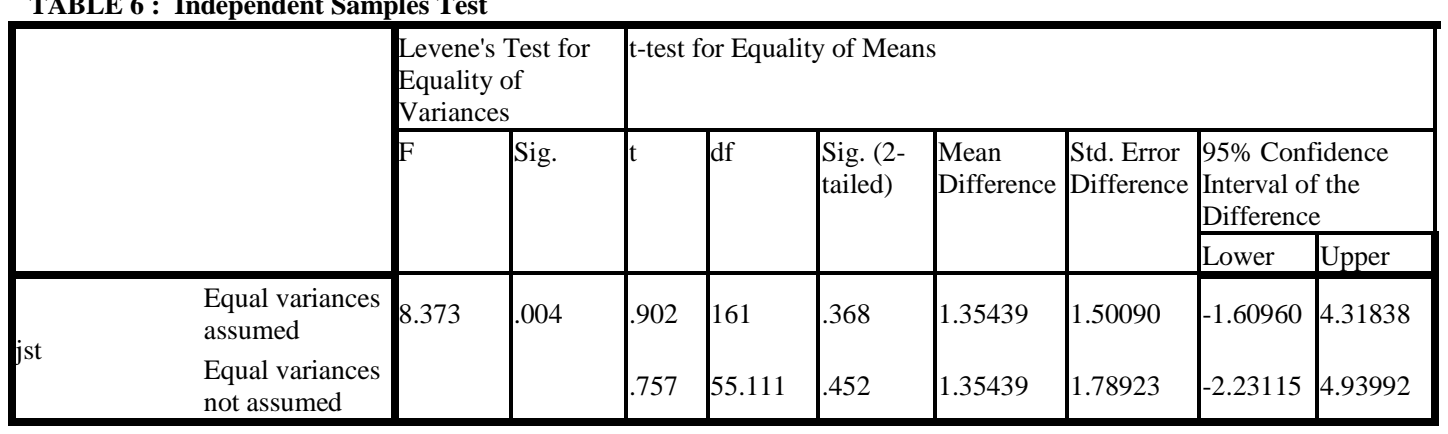

7.3 Satisfaction level across Academic streams (Assistant professors)

In this study we took three stream namely Arts, science and commerce/economics to see the whether Assistant Professors are equally satisfied across all major streams of academics.

As there are three independent samples, so to apply ANOVA we have to test Homogeneity of Variances. At a significance level of 5\% there is no difference between Variances among groups.

TABLE 7 : Test of Homogeneity of Variances

Jst

\begin{tabular}{|l|l|l|l|}
\hline Levene Statistic & df1 & df2 & Sig. \\
\hline 1.215 & 2 & 118 & .300 \\
\hline
\end{tabular}

At a significance level of 5\%, satisfaction level among different academic streams is significantly different as p- value (.000) is less than 0.05 . Or we can say at least on group satisfaction level is significantly different. 
TABLE 8 : ANOVA

Job Satisfaction

\begin{tabular}{|l|l|l|l|l|l|}
\hline & Sum of Squares & Df & Mean Square & F & Sig. \\
\hline Between Groups & 984.857 & 2 & 492.429 & 10.395 & .000 \\
Within Groups & 5589.919 & 118 & 47.372 & & \\
Total & 6574.777 & 120 & & & \\
\hline
\end{tabular}

The above table is for multiple comparisons of Assistant professors across different academic streams.

Dependent Variable: Job Satisfaction

Tukey HSD TABLE9 : Multiple Comparisions

\begin{tabular}{|c|c|c|c|c|c|c|}
\hline \multirow{2}{*}{$\begin{array}{l}\text { (I) Acad Stream of } \\
\text { respondent }\end{array}$} & \multirow{2}{*}{$\begin{array}{l}(\mathrm{J}) \text { Acad Stream of } \\
\text { respondent }\end{array}$} & \multirow{2}{*}{$\begin{array}{l}\text { Mean } \\
\text { Difference (I- } \\
\text { J) }\end{array}$} & \multirow{2}{*}{ Std. Error } & \multirow[t]{2}{*}{ Sig. } & \multicolumn{2}{|c|}{$95 \%$ Confidence Interval } \\
\hline & & & & & $\begin{array}{l}\text { Lower } \\
\text { Bound }\end{array}$ & $\begin{array}{l}\text { Upper } \\
\text { Bound }\end{array}$ \\
\hline \multirow{4}{*}{$\begin{array}{l}\text { arts } \\
\text { commerce/economics }\end{array}$} & commerce/economics & $-6.51648^{*}$ & 1.44302 & .000 & -9.9417 & -3.0913 \\
\hline & science & $-5.27619^{*}$ & 1.89982 & .017 & -9.7857 & -.7667 \\
\hline & arts & $6.51648^{*}$ & 1.44302 & .000 & 3.0913 & 9.9417 \\
\hline & science & 1.24029 & 1.72761 & .753 & -2.8604 & 5.3410 \\
\hline \multirow{2}{*}{ science } & arts & $5.27619^{*}$ & 1.89982 & .017 & .7667 & 9.7857 \\
\hline & commerce/economics & -1.24029 & 1.72761 & .753 & -5.3410 & 2.8604 \\
\hline
\end{tabular}

*. The mean difference is significant at the 0.05 level.

At significance level of 5\%, satisfaction level of Assistant professors in commerce/economics is significantly different from Assistant professors in Arts. Although both faculty member are satisfied but on the basis of mean value faculty incommerce/economics (mean= 64.43) are more satisfied then faculty in arts $($ mean $=57.91)$.

On the basis of satisfaction Assistant professors in Science are also significantly different from Assistant professors in Arts at a significance level of 5\%. Although both faculty members are satisfied and on the bases of mean value of satisfaction level faculty in Science (mean=63.19) are more satisfied then faculty in arts (mean= 57.19).

Assistant professors in Science are not significantly different from Assistant professors in commerce/economics at a significance level of 5\% for satisfaction level. Both faculty members are satisfied and on the basis of mean value of satisfaction level faculty in Science (mean=63.19) are less satisfied then faculty in commerce/economics (mean= 57.19).

Tukey HSD

TABLE 10 : Job Satisfaction

\begin{tabular}{|l|l|l|l|}
\hline Academic Stream of respondent & N & \multicolumn{3}{|l|}{ Subset for alpha $=0.05$} \\
\cline { 3 - 4 } & & 1 & 2 \\
\hline Arts & 35 & 57.9143 & 63.1905 \\
Science & 21 & & 64.4308 \\
commerce/economics & 65 & & 747 \\
Sig. & & 1.000 & .747 \\
\hline
\end{tabular}

Means for groups in homogeneous subsets are displayed.

a. Uses Harmonic Mean Sample Size $=32.760$.

$b$. The group sizes are unequal. The harmonic mean of the group sizes is used. Type I error levels are not guaranteed.

The mean plot (below) of different academic streams shows satisfaction level of Assistant faculty members across different streams. 


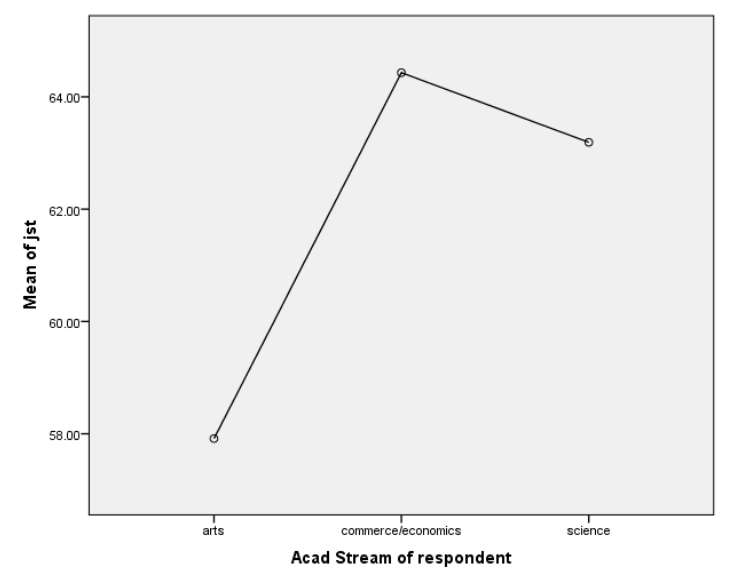

\subsection{Satisfaction level across Academic streams (Associate Professors)}

As there are three independent samples, so to apply ANOVA we have to test Homogeneity of Variances. At a significance level of 5\% there is no difference between Variances among groups.

TABLE 11 :Test of Homogeneity of Variances

Job Satisfaction
\begin{tabular}{|l|l|l|l|}
\hline Levene Statistic & df1 & df2 & Sig. \\
\hline .847 & 2 & 39 & .436 \\
\hline
\end{tabular}

At a significance level of 5\%, satisfaction level among academic streams is not significantly different as p- value (.338) is more than 0.05 , so on the basis of these results we can say that Associate professor among different streams equally satisfied.

\section{Table 12 : ANOVA}

\begin{tabular}{|c|c|c|c|c|c|}
\hline & Sum of Squares & $\mathrm{df}$ & Mean Square & $\mathrm{F}$ & Sig. \\
\hline Between Groups & 256.363 & 2 & 128.181 & 1.117 & .338 \\
\hline Within Groups & 4476.614 & 39 & 114.785 & & \\
\hline Total & 4732.976 & 41 & & & \\
\hline
\end{tabular}

\subsection{Satisfaction level of Assistant Professors across Gender}

As sample size is two (Males \& Females) so "T" test can be applied as samples are independent.

In this study, mean score of job satisfaction in Males is 62.91 and SD is 7.15. This means Male faculty is satisfied. In comparison between Females and Males, mean score of job satisfaction in Females is 61.83 and $\mathrm{SD}$ is 7.63. This means Female faculty is also satisfied.

At significance level of 5\%, job satisfaction of males and females is not significantly different as $p$ value shows .426 which is more than .05 , means both are equally satisfied.

TABLE 13 : Independent Samples Test

\begin{tabular}{|c|c|c|c|c|c|c|c|c|c|c|}
\hline & & \multicolumn{2}{|c|}{$\begin{array}{l}\text { Levene's Test for } \\
\text { Equality of Variances }\end{array}$} & \multicolumn{7}{|c|}{ t-test for Equality of Means } \\
\hline & & \multirow[t]{2}{*}{$\mathrm{F}$} & \multirow[t]{2}{*}{ Sig. } & \multirow[t]{2}{*}{$\mathrm{t}$} & \multirow[t]{2}{*}{ df } & \multirow[t]{2}{*}{$\begin{array}{l}\text { Sig. (2- } \\
\text { tailed) }\end{array}$} & \multirow[t]{2}{*}{$\begin{array}{l}\text { Mean } \\
\text { Difference }\end{array}$} & \multirow{2}{*}{$\begin{array}{l}\text { Std. Error } \\
\text { Difference }\end{array}$} & \multicolumn{2}{|c|}{$\begin{array}{l}95 \% \text { Confidence } \\
\text { Interval of the } \\
\text { Difference } \\
\end{array}$} \\
\hline & & & & & & & & & Lower & Upper \\
\hline \multirow{2}{*}{ jst } & $\begin{array}{l}\text { Equal variances } \\
\text { assumed }\end{array}$ & \multirow[t]{2}{*}{.121} & \multirow[t]{2}{*}{.729} & -.799 & 119 & .426 & -1.07995 & 1.35160 & -3.75624 & 1.59635 \\
\hline & $\begin{array}{l}\text { Equal variances not } \\
\text { assumed }\end{array}$ & & & -.803 & 118.139 & .424 & -1.07995 & 1.34503 & -3.74344 & 1.58355 \\
\hline
\end{tabular}




\subsection{Satisfaction level of Associate Professors across Gender}

As sample size is two so "T" test can be applied as samples are independent. In comparison between Males and Females, mean score of job satisfaction in Male is 61.91 and SD is 10.46. This means Male faculty at associate level is satisfied

Mean score of job satisfaction in Females is 59.58 and SD is 11.25 . This means Female faculty are satisfied.

Both faculty members are satisfied.

TABLE 14 : Group Statistics

\begin{tabular}{|l|l|l|l|l|l|}
\hline & Gender of respondent & N & Mean & Std. Deviation & Std. Error Mean \\
\hline \multirow{2}{*}{ jst } & Female & 19 & 59.8421 & 11.25099 & 2.58115 \\
& Male & 23 & 61.9130 & 10.46602 & 2.18232 \\
\hline
\end{tabular}

At significance level of 5\%, job satisfaction of male and female is not significantly different as p value shows .541 which is more than .05 , both are equally satisfied.

TABLE 16 :Independent Samples Test

\begin{tabular}{|c|c|c|c|c|c|c|c|c|c|c|}
\hline & \multicolumn{2}{|c|}{$\begin{array}{l}\text { Levene's Test for } \\
\text { Equality of Variances }\end{array}$} & \multicolumn{7}{|c|}{ T-test for Equality of Means } \\
\hline & & \multirow[t]{2}{*}{$\mathrm{F}$} & \multirow[t]{2}{*}{ Sig. } & \multirow[t]{2}{*}{$\mathrm{t}$} & \multirow[t]{2}{*}{ df } & \multirow[t]{2}{*}{$\begin{array}{l}\text { Sig. (2- } \\
\text { tailed) }\end{array}$} & \multirow[t]{2}{*}{$\begin{array}{l}\text { Mean } \\
\text { Difference }\end{array}$} & \multirow[t]{2}{*}{$\begin{array}{l}\text { Std. Error } \\
\text { Difference }\end{array}$} & \multicolumn{2}{|c|}{\begin{tabular}{|l} 
95\% Confidence \\
Interval of the \\
Difference \\
\end{tabular}} \\
\hline & & & & & & & & & Lower & Upper \\
\hline \multirow{2}{*}{ jst } & $\begin{array}{l}\text { Equal variances } \\
\text { assumed }\end{array}$ & .205 & .653 & -.617 & 40 & .541 & -2.07094 & 3.35633 & -8.85432 & 4.71245 \\
\hline & $\begin{array}{l}\text { Equal variances not } \\
\text { assumed }\end{array}$ & & & -.613 & 37.326 & .544 & -2.07094 & 3.38007 & -8.91759 & 4.77571 \\
\hline
\end{tabular}

7.7 Causes of job satisfaction and job dissatisfaction 7.7.1 Assistant Professors

TABLE 17 : Descriptive Statistics

\begin{tabular}{|l|l|l|l|l|l|}
\hline & N & Mean & Std. Deviation & Minimum & Maximum \\
\hline Work acc. to qualification and skills & 121 & 4.4793 & .62047 & 2.00 & 5.00 \\
Job security & 121 & 3.0083 & 1.33851 & 1.00 & 5.00 \\
Conducive atmosphere contributing to & 121 & 3.7107 & .87975 & 1.00 & 5.00 \\
growth & 121 & 3.9835 & .74143 & 1.00 & 5.00 \\
Academic challenges & 121 & 3.2810 & .98508 & 1.00 & 5.00 \\
Learning opportunities & 121 & 4.0579 & .71060 & 2.00 & 5.00 \\
Cooperation from colleagues & 121 & 3.9752 & .79018 & 2.00 & 5.00 \\
Workload manageable & 121 & 3.9917 & .77991 & 2.00 & 5.00 \\
Seniors responsive to needs & 121 & 4.5702 & .58916 & 2.00 & 5.00 \\
Student interaction & 121 & 3.8595 & .81961 & 2.00 & 5.00 \\
Sufficient freedom & 121 & 3.545 & .8563 & 1.0 & 5.0 \\
Work recognition & 3.4215 & .91060 & 1.00 & 5.00 \\
Growth opportunities & 121 & 3.5289 & .86674 & 1.00 & 5.00 \\
Employee friendly management & 121 & & & \\
policies & 121 & 2.7934 & 1.21736 & 1.00 & 5.00 \\
involves in management decisions & 121 & 3.8678 & .82606 & 1.00 & 5.00 \\
Satisfactory salary & 121 & 3.2314 & 1.25672 & 1.00 & 5.00 \\
Satisfactory academic infrastructure & 121 & 3.0248 & 1.22108 & 1.00 & 5.00 \\
Welfare facilities & 121 & & \\
\hline
\end{tabular}

There are total 121 assistant professors in our sample. Assistant professors are satisfied with work acc. to qualification and skills (mean= 4.47) and student interaction (mean=4.57) in class room, and dissatisfied of management decision involvement (mean= 2.79). 


\subsubsection{Associate Professors}

TABLE 18 : Descriptive Statistics

\begin{tabular}{|c|c|c|c|c|c|}
\hline & $\mathrm{N}$ & Mean & Std. Deviation & Minimum & Maximum \\
\hline Work acc. to qualification and skills & 42 & 4.4048 & .79815 & 2.00 & 5.00 \\
\hline Job security & 42 & 4.5000 & .55216 & 3.00 & 5.00 \\
\hline $\begin{array}{l}\text { Conducive atmosphere contributing to } \\
\text { growth }\end{array}$ & 42 & 3.3095 & 1.09295 & 1.00 & 5.00 \\
\hline Academic challenges & 42 & 3.5952 & 1.01356 & 1.00 & 5.00 \\
\hline Learning opportunities & 42 & 2.8095 & .96873 & 1.00 & 5.00 \\
\hline Cooperation from colleagues & 42 & 3.6190 & 1.01097 & 2.00 & 5.00 \\
\hline Workload manageability & 42 & 3.6667 & 1.11894 & 1.00 & 5.00 \\
\hline Responsive seniors & 42 & 3.5476 & .86115 & 2.00 & 5.00 \\
\hline Student interaction & 42 & 4.5238 & .67130 & 2.00 & 5.00 \\
\hline Sufficient freedom & 42 & 3.9524 & .82499 & 2.00 & 5.00 \\
\hline Work recognition & 42 & 3.690 & .9497 & 1.0 & 5.0 \\
\hline Growth opportunities & 42 & 3.0476 & .98655 & 1.00 & 5.00 \\
\hline Employee friendly management policies & 42 & 3.3095 & 1.04737 & 1.00 & 5.00 \\
\hline Involvement in management decisions & 42 & 2.7381 & 1.28897 & 1.00 & 5.00 \\
\hline Satisfactory salary & 42 & 4.2857 & .67302 & 2.00 & 5.00 \\
\hline Satisfactory academic infrastructure & 42 & 3.0238 & 1.29705 & 1.00 & 5.00 \\
\hline Welfare facilities & 42 & 2.9524 & 1.22877 & 1.00 & 5.00 \\
\hline
\end{tabular}

There are total 42 Associate professors in our sample. Associate professors are satisfied with work according to qualification and skills (mean= 4.40) and student interaction $($ mean= 4.52) in class room, and dissatisfied due to inadequate management decision involvement $($ mean $=2.73)$.

\section{Conclusion}

As per the findings described in this study, there was no significant difference in job satisfaction level of Assistants professor and Associate professors. This is a sign that teachers are unmindful of the designation they work at in the university. However, there is significant difference in job satisfaction level of Assistant professor in arts and commerce/economics. in the case of arts and science, science and commerce/economics no significant difference was found. Male assistant Professor and Female assistant Professors are also not significantly different w.r.t job satisfaction level.

In the case of associate professors, no significant difference in job satisfaction level of arts, commerce/economics and science faculty members. Similarly on the basis of gender, Male associate Professor and Female associate Professors are also not significantly different w.r.t job satisfaction level

Both Assistant professors and Associate professors in Delhi University are satisfied with work acc. to qualification and skills and student interaction.

Both Assistant professors and Associate professors are dissatisfied with involvement in management decision. This indicates that decision making is concentrated only at the topmost level.

\section{Limitations Of The Study}

In this study, the data obtained through questionnaires were all self-reports from the participants to determine which aspects of their position are satisfying and dissatisfying, hence, the findings may be subject to response consistency effect. On the other hand, this study cannot be generalized to all other university in India; the findings of this study are restricted to the University of Delhi which the samples were drawn. Also, the highest hierarchy, i.e. Professors have not been considered due to there being a handful number of them as compares to hundreds working at lower levels.

\section{References}

[1] 'Job satisfaction and gender factor of administrative staff in South West Nigeria universities'.Olorunsola, O.E. (2010) EABR \& ETLC Conference proceedings Dublin, Ireland, 91-95

[2] Abdul, Q.C. (2013), 'Job satisfaction of university teachers across the demographic. Bulletin of Education and Research' Pp 1-15

[3] C.L. \& Au, W.T. (2006), Teaching satisfaction scale: measuring job satisfaction of teachers, Educational and psychological Measurement, 66, 172-185

[4] Gautam, M., Mandal, K. \&Dalal (2006), 'Job satisfaction of faculty members of veterinary sciences: An Analysis. Livestock Research for Rural development 
[5] Ghafoor, M.M. (2012), Role of demographic characteristics on job satisfaction, Far East Research Centre

[6] Ghazi, S.R., Ali, R., Shahzada, G. \&Israr, (2010), 'University teachers' job satisfaction in the North West Frontier province of Pakistan'

[7] Jaime X. Castillo \& Jamie Cano (2004) 'Factors explaining job satisfaction among faculty', Journal of Agriculture Education, Vol $45,65-74$

[8] M.R.(1999),Teacher job satisfaction in developing countries. Educational research supplemental series, ERIC Document Reproduction Service No. ED 458150

[9] Malik, N. (2011), Study on job satisfaction factors of faculty members at university of Balochistan, International Journal of Academic Research, 267-272

[10] Mehboob, F., Sarwar, M.A. \& Bhutto, N.A. (2012), 'Factors affecting job satisfaction among faculty members, Asian Journal of Business and Management Sciences, 1 (12), 1-9

[11] Noordin, F. \&Jusoff, K. (2009), Levels of job satisfaction amongst Malaysian academic staff. Asian Social Science, 5 (5), $122-128$

[12] Platsidou, M.,\&Diamantopoulou, G. (2009), Job satisfaction of Greek university professors: Is it affected by demographic factors, academic rank and problem of higher education?

[13] http://www.informaworld.com/smppcontent $\sim$ content=a713677196?

words=factors

$\% 7$ crelated $\% 7 \mathrm{cjob} \% 7 \mathrm{c}$

[14] hatisfaction\&hash=2182297297
http://ies.ed.gov/ncee/wwc/pdf/practiceguides/Turnaround_pg_04181.pdf 